\title{
As tecnologias de comunicação e informação na escola; relações possíveis... relações construídas
}

\section{Tania Maria Esperon Porto}

Universidade Federal de Pelotas, Faculdade de Educação

A mulher entra no quarto do filho decidida a ter uma

conversa séria. De novo, as respostas dele à interpretação do texto na prova sugerem uma grande dificuldade de ler. Dispersão pode ser uma resposta para parte do problema. A extensão do texto pode ser outra, mas nesta ela não vai tocar

porque também é professora e não vai lhe dar desculpas para ir mal na escola. Preguiça de ler parece outra forma de

lidar com a extensão do texto. Ele está, de novo, no

computador, jogando. Levanta os olhos com aquele ar de

quem pode jogar e conversar ao mesmo tempo. A mãe lhe pede que interrompa o jogo e ele pede à mãe "só um instante para salvar". Curiosa, ela olha para a tela e se espanta com o jogo em japonês. Pergunta-lhe como consegue entender o texto para jogar. Ele lhe fala de alguma coisa parecida com

uma "lógica de jogo" e sobre algumas tentativas com os ícones. Diz ainda que conhece a base da história e que, assim, mesmo em japonês, tudo faz sentido. Aquela conversa acabou sendo adiada. A mãe-professora não se sentia pronta naquele momento.

Raquel Barreto (2002, p.75)

\section{Introdução}

Novas formas de pensar, de agir e de comunicarse são introduzidas como hábitos corriqueiros. Nunca tivemos tantas alterações no cotidiano, mediadas por múltiplas e sofisticadas tecnologias. As tecnologias invadem os espaços de relações, mediatizando estas e criando ilusão de uma sociedade de iguais, segundo um realismo presente nos meios tecnológicos e de comunicação. No entender de Sarlo (1998), as desigualdades são marcadas pela ilusão de um realismo que permitiria a todos participar com iguais condições dos diferentes espaços e meios proporcionados pela sociedade capitalista e essencialmente tecnológica. O mercado audiovisual e tecnológico cria a ilusão de a todos servir, embora muitos se contentem apenas com o fast-food televisivo e com a esperança de um dia poder acessar todos os bens. Consumidores efetivos e consumidores imaginários reforçam os objetivos do mercado. 
São vencidas barreiras geográficas e criadas aproximações culturais, apesar das diferenças econômicas e dos obstáculos socioculturais que se interpõem para a produção dos desejos nos cidadãos. As distâncias e os espaços que os meios tendem a aproximar e a globalizar concorrem para que as necessidades se assemelhem, mesmo que, para muitos, a satisfação delas não se concretize.

Lévy (2000), numa análise das mutações contemporâneas, traz para debate a velocidade do surgimento de informações e da renovação destas, dos dados e das redes que se criam/interconectam. Para o autor, os contatos transversais entre indivíduos proliferam de forma anárquica, produzindo "guerra" de imagens, propagandas e contrapropagandas.

Analisar o papel que as tecnologias e as informações/imagens tem desempenhado na vida social implica não somente explorar as características técnicas dos meios, mas buscar entender as condições sociais, culturais e educativas de seus contextos. Esse enfoque é primordial para perceber as possibilidades que se estabelecem com o uso das modernas - algumas já nem tão modernas assim - tecnologias.

A tecnologia não é boa nem má, dependendo das situações, usos e pontos de vista, e "tampouco neutra, já que é condicionante ou restritiva, já que de um lado abre e de outro fecha o espectro de possibilidades". Não se trata de avaliar seus impactos, mas de situar possibilidades de uso, embora, "enquanto discutimos possíveis usos de uma dada tecnologia, algumas formas de usar já se impuseram", tal a velocidade e renovação com que se apresentam (Lévy, 2000, p. 26).

Para Kenski (2003), a evolução tecnológica não se restringe aos novos usos de equipamentos e/ou produtos, mas aos comportamentos dos indivíduos que interferem/repercutem nas sociedades, intermediados, ou não, pelos equipamentos. Portanto, entendemos como tecnologias os produtos das relações estabelecidas entre sujeitos com as ferramentas tecnológicas que têm como resultado a produção e disseminação de informações e conhecimentos.

Assim, a escola defronta-se com o desafio de trazer para seu contexto as informações presentes nas tecnologias e as próprias ferramentas tecnológicas, articulando-as com os conhecimentos escolares e propiciando a interlocução entre os indivíduos. Como conseqüência, disponibiliza aos sujeitos escolares um amplo leque de saberes que, se trabalhados em perspectiva comunicacional, garantem transformações nas relações vivenciadas no cotidiano escolar (Porto, 2003; Marcolla, 2004).

As novas (e velhas) tecnologias podem servir tanto para inovar como para reforçar comportamentos e modelos comunicativos de ensino. A simples utilização de um ou outro equipamento não pressupõe um trabalho educativo ou pedagógico. No entender de Orozco (2002), o "tecnicismo por si só não garante uma melhor educação. [...] se a oferta educativa, ao se modernizar com a introdução das novas tecnologias, se alarga e até melhora, a aprendizagem, no entanto, continua uma dúvida" (p. 65). Para o autor, cada meio e cada tecnologia exercem uma mediação particular nas pessoas e contextos com os quais interatuam, pressupondo transformações na organização do trabalho, nos seus componentes e, conseqüentemente, na instituição educativa que realiza o trabalho.

Além disso, os contextos (sociais, culturais e financeiros) também têm um papel definidor entre o sujeito e a tecnologia, ampliando e/ou limitando as relações e situações que daí se originam. Por exemplo, na história da epígrafe, mesmo que a mãe-professora quisesse preparar-se para atuar na escola com a tecnologia do game, ela poderia encontrar obstáculos com a direção, coordenação, ou mesmo com os pais da instituição onde atua, por não estarem preparados para aceitar a inclusão de um jogo ou brinquedo infantil em situação pedagógica. Apesar de nos depararmos com informações/imagens que chegam sob diferentes apelos sensoriais - visuais, auditivos e emocionais -, incorrendo em diferentes formas de aprendizagem além da razão (intuição, emotividade, criatividade e relacionamentos), ainda muitas escolas não estão abertas para a incorporação, ou, quem sabe, para o desafio de um trabalho com essas linguagens em seus cotidianos. Diante dessas linguagens, a grande maioria dos docentes (ou mesmo pais) se vê 
apenas como usuário/telespectador. A preparação social e/ou pedagógica para seu uso não é, na maioria das vezes, cogitada.

Babin e Kouloumdjian (1989), em suas pesquisas com os jovens ante a realidade da comunicação advinda com os avanços das tecnologias, confirmam a hipótese de que a invasão das mídias e o emprego das tecnologias na vida cotidiana modelam progressivamente um outro comportamento intelectual e afetivo. Os jovens “estão em outra", afirmam os autores, e isso significa outras necessidades, outras percepções, outros relacionamentos, além daqueles conhecimentos muitas vezes vazios de significados que lhes chegam por meio das escolas e dos livros, organizados racional e linearmente. São outras maneiras de compreender, de perceber, de sentir e de aprender, em que a afetividade, as relações, a imaginação e os valores não podem deixar de ser considerados. São alternativas de aprendizagem que os auxiliam a interagir, a escolher e a participar nas estruturas sociais e educativas.

Assim, com este texto, pretendo, num primeiro momento, refletir sobre as relações entre as tecnologias e a ação educativa escolar para, num segundo momento, chegar a um processo de formação docente na escola com o uso de tecnologias, mais especificamente, da comunicação. Refiro-me a estas não apenas como equipamentos e/ou ferramentas, mas como um conjunto de processos usados em interação entre pessoas, que põem em discussão questões individuais, referentes aos interesses e subjetividades dos sujeitos, e questões coletivas, referentes aos contextos socioculturais dos indivíduos. Assim, as tecnologias de informação e/ou comunicação possibilitam ao indivíduo ter acesso a uma ampla gama de informações e complexidades de um contexto (próximo ou distante) que, num processo educativo, pode servir como elemento de aprendizagem, como espaço de socialização, gerando saberes e conhecimentos científicos.

\section{A escola e as tecnologias}

Procurando elementos para reflexão que nos permitam compreender as mudanças que acontecem nos contextos por elas mediados, trago algumas considerações sobre relações entre escola e tecnologias, tomando como exemplo a história narrada na epígrafe deste texto.

Embora existam avaliações que evidenciem problemas com o uso de tecnologias em processos educativos (Orozco, 2002; Gutiérrez Martín, 2002), optei por abordar suas possibilidades, fazendo interlocução com a história de Barreto (2002) e as idéias de Gutiérrez Martín (1998, 2002), considerando que o potencial educativo das tecnologias pressupõe uma sensibilização e preparação docente para o uso, considerando o contexto de ação. Dessa forma, exponho a seguir observações sobre o potencial educativo de alguns elementos que pertencem a essas novas tecnologias: rapidez, recepção individualizada, interatividade e participação, hipertextualidade, realidade virtual e digitalização/ideologia.

Rapidez. A rapidez com que são disponibilizadas e processadas as informações é uma das características das novas tecnologias. As informações chegam até nós como não imaginávamos há 20 anos. Na história narrada na epígrafe, a mãe-professora sente-se impotente perante o filho, que consegue processar/ ler informações que ela (tradicionalmente responsável pela função de ensinar) não consegue. Ela vem com "outros sentidos" sobre o ato de ler e interpretar textos, segundo a lógica da cognição que não a preparou para compreender e contextualizar imagens e ícones em japonês. O filho mostra-lhe um processo de leitura que vai além dos textos impressos. Está em jogo uma leitura não limitada à extração de informações do texto, conforme a escola solicita e espera. Está no game uma outra intencionalidade, uma dimensão lúdica, uma busca de emoções e de sentidos associados à "lógica do jogo e às tentativas com os ícones", habilidades adquiridas pelo menino, provavelmente sem o auxílio da escola. Ele, como os demais meninos da realidade atual, é capturado pelas múltiplas linguagens e sentidos das tecnologias. $\mathrm{Na}$ maioria das vezes, a escola prepara para ler símbolos (palavras e frases) em textos escritos, sem a consideração de imagens e/ou outras linguagens dos diferen- 
tes suportes tecnológicos presentes na realidade atual e, principalmente, sem a preparação para a abundância de "novidades" impostas pelo mercado tecnológico. Os meios tecnológicos e seus numerosos produtos chegam ao menino destinatário de forma direta e imediata, influenciando-o sem que outros agentes educativos (no caso da história, a mãe-professora, que representa a educadora) atuem como mediadores.

Recepção individualizada. As tecnologias põem à disposição do usuário amplo conjunto de informações/conhecimentos/linguagens em tempos velozes e com potencialidades incalculáveis, disponibilizando, a cada um que com elas se relacione, diferentes possibilidades e ritmos de ação. O menino da história em questão vive, com o game, tempo e conhecimento específicos. Envolve-se com a tecnologia segundo seu modo de ser e ver a realidade, utilizando-se das representações pessoais e sociais para compor sua leitura/interação ou (re)criar valores e conceitos. Tornase operador de imagens/mensagens, significando que realiza uma construção mental específica, de interação com o meio e significação desse (Porto, 2002). A grande maioria dos docentes que a mãe-professora representa trabalha numa única direção - grande grupo sem consideração aos anseios e necessidades individuais dos estudantes. São 35 a 40 alunos em classe, dificultando a aproximação do professor com o universo e as subjetividades dos alunos, situação mais facilmente atendida pelo videogame, que apresenta caminhos a serem escolhidos pelo usuário de acordo com suas possibilidades.

Interatividade e participação. Uma relação interativa com os meios permite ao usuário assumir o papel de sujeito. Para Gutiérrez Martín (2002), os novos sistemas multimídias são quase humanos, pois possibilitam uma relação próxima de diálogo e comunicação exclusiva dos indivíduos. O menino da história não consegue se relacionar com os textos escolares da mesma forma que com o jogo, pois este lhe permite realizar interação com os personagens e ser sujeito da situação. Neste tipo de jogo, o usuário é estimulado a querer participar, a discutir e compartilhar as descobertas com os amigos. Ele identifica-se intensamente com o enredo, vivendo, mesmo que por procuração, uma relação com sentido, como se fosse um dos personagens do jogo. Ele tem o poder de construir e intervir na história, escolher os caminhos, bastando, para isso, "apertar teclas para salvar". Sua interação acontece com a máquina, personagens e situações nela presentes. Nesse processo, ele explora caminhos, cria e experimenta possibilidades - o que muitas vezes não lhe é possibilitado pela escola, em nome de atender às exigências curriculares. Uma escola que, na maioria das vezes, está distante do universo dos jogos eletrônicos e não incentiva a autonomia e participação entre os jovens, possibilitando ensinamentos e experiências descontextualizadas do universo adolescente.

Hipertextualidade. O hipertexto do game é um texto estruturado em nós, com abundância de informações, imagens, janelas, caminhos e linguagens que os textos escolares não possibilitam. O texto virtual permite associações, mixagens, e faz com que o usuário tenha diferentes opções de escolha, seja sujeito em busca da complexidade de informações/caminhos que, na maioria dos processos escolares, não é usual. A complexidade do mundo moderno não está presente nos ensinamentos da sala de aula. As relações de causa e efeito, o encadeamento linear seriado dos currículos escolares não dá conta, por exemplo, de situações vividas pelos jovens em contato com outros jovens e/ou em situações do dia-a-dia de incertezas, acertos, erros, medos, entre outros aspectos. Nos jogos (eletrônicos ou não), a ubiquiidade de opções/vivências leva o estudante a diferentes caminhos. Mais do que os fins, os caminhos do jogo são procurados. O jovem da história faz associações, compara situações entre o que conhece em sua língua (português) com o que está em outra língua (japonês) para significar sua leitura. Jogando, sua aprendizagem tem significação e ele busca vencer imprevistos, descobrir alternativas que o tornem mais competente em suas escolhas e decisões, embora na maioria das vezes aconteçam por ensaio e erro. Assim, percebemos que a educação com hipertextos possibilita ações de decisão ao estudante, que é o responsável pela seleção e 
produção de caminhos/informações. Não propomos à escola a exclusão de textos lineares e imagéticos com que tradicionalmente vem trabalhando (entendidos como recursos audiovisuais e de consulta), mas uma agregação, a estes, de jogos e de outras linguagens tecnológicas e comunicacionais que permitam ao usuário a seleção, busca e mixagem de informações, de situações de aprendizagem e, conseqüentemente, o diálogo com a realidade atual.

Realidade virtual. Como o tempo virtual impõese ao espaço real, como a imagem impõe-se sobre o objeto e o virtual impõe-se ao atual, o indivíduo interage com a realidade das imagens, criando elementos próprios para entender a situação virtual, significá-la e interagir com ela. De acordo com Lévy, o virtual é o que existe em potência, e não em ato. Enquanto a realidade pressupõe uma efetivação material, uma presença tangível, o virtual é um "passe de mágica misterioso"; contudo, o virtual não se opõe ao real, são apenas "dois modos diferentes da realidade" (2000, p. 47). Na história da epígrafe, a realidade virtual do jogo produz fantasias percebidas pelo menino, que estabelece com ela uma analogia, pois "mesmo em japonês, tudo faz sentido". A navegação na Internet ou a imersão que os games possibilitam faz com que o usuário vivencie situações com sentido, que, muitas vezes, não são possíveis de serem vividas na realidade escolar da maioria das escolas. A realidade virtual prazerosa tem um pequeno lugar pedagógico, principalmente nos primeiros anos escolares, com a fantasia das histórias vividas/contadas; entretanto, na continuidade da vida escolar são mais trabalhados textos formais, distantes das emoções, dos desejos e do conhecimento informal do cotidiano. Entendemos que o prazer na aprendizagem pode ser obtido com modernas tecnologias, como o videogame e a Internet, assim como com tecnologias mais tradicionais, como a leitura e escritura de textos, desde que respondam aos anseios imaginários dos estudantes e propiciem vivências significativas e criativas para eles.

Digitalização/ideologia. Os meios/tecnologias têm diferentes linguagens que lhes permitem se inter- relacionar com outras linguagens. Com especificidades próprias - imagens, narrativas, sons e movimentos -, o meio chega ao receptor com fortes apelos de sedução, contribuindo para que o usuário crie códigos de entendimento e se envolva com as mensagens nele divulgadas. Há uma enorme distância entre o criador/produtor do meio e o usuário. O menino da história já tem domínio do código "digitalizado" do game, movimentando-se com naturalidade por entre as linguagens, representações e posturas do jogo. Na história em análise, o game possibilita ao menino selecionar e/ou descartar as informações de que necessita para jogar. O game é uma atividade lúdica com sentido que permite construção e desenvolvimento de habilidades cognoscitivas, apesar de os jovens jogadores não terem consciência disso. "Serve para construção e desenvolvimento da inteligência, exercita o pensamento simbólico, a assimilação e a acomodação [...] é através das manipulações rudimentares que o menino se aproxima pouco a pouco, mas a passo seguro, da ação e pensamento" (Quiroz \& Tealdo, 1996, p. 45), buscando informações que, conseqüentemente, serão transformadas em conhecimentos, valores e conceitos significativos para seu universo. Apesar desse domínio pela grande maioria das crianças e jovens, acreditamos ser responsabilidade da escola auxiliar no entendimento e reflexão sobre o que está presente nas imagens/mensagens das tecnologias, e encaminhar para a percepção do que está por trás das linguagens, na maioria das vezes, icônicas. A escola, assim, possibilita que os alunos, "agentes sociais por natureza, mergulhem na realidade das imagens/mensagens, procurando, primeiramente, compreendê-las pelas experiências, para depois proceder ao distanciamento reflexivo e pensar sobre elas" (Porto, 2000, p. 130).

Com essas reflexões sobre o potencial educativo das tecnologias, verificamos que a escola e os meios tecnológicos de comunicação e informação caminham em paralelo. Ambos retratam a realidade e a cotidianidade; apresentam valores, conceitos e atitudes presentes na realidade em geral, que são absorvidos sob diferentes matizes. Os meios são de livre escolha, regem-se 
pela lógica do mercado, contribuem para a criação e reprodução da ideologia dominante, sendo, porém, atraentes e socialmente legitimados; a outra, a escola, é impositiva e, de certa forma, sem atrativos, socialmente legitimadora do saber, do conhecimento, reproduzindo a ideologia dominante (Porto, 2000).

Assim, os saberes adquiridos pelos estudantes (e pelos professores) não estão apenas na escola e na família. Estão na vida, nas relações com os amigos e com os meios de comunicação. Ingenuamente, alguns professores não percebem a presença dos meios/tecnologias na escola (na cultura dos alunos que a ela acorrem), ou mesmo desconhecem os mecanismos de sedução neles presentes. Afirmam ser imprescindível ensinar os alunos a educar-se para os meios, entendendo que lhes basta ter espírito crítico. Esta consideração, no entender de Ferrés (2000), é ingênua e parcial, pois os meios, com sua lógica própria (das emoções), chegam aos usuários atendendo a diferentes anseios (tensões, esperanças, necessidades, desejos, temores) não considerados pela escola tradicional.

Ao contrário do homem da era de Gutenberg, treinado para a racionalização e a distância afetiva, o homem da civilização técnico-eletrônica e audiovisual, no entender de Babin e Kouloumdjian (1989), conecta intimamente a sensação à compreensão, a coloração imaginária ao conceito. Sem afetividade não há audiovisual. Esta nova linguagem tecnológica, que interconecta e aproxima os indivíduos, também treina múltiplas atitudes perceptivas e solicita constantemente a imaginação, investindo na afetividade e nas relações como mediação primordial no mundo. São possibilidades de linguagens tecnológicas que podem incorporar-se à escola para ensinar o respeito ao diferente, a vencer obstáculos, a trabalhar coletivamente, entre outros aspectos. Não pressupõe uma didática nova, mas uma postura que se apóia na inter-relação entre professor e alunos como sujeitos que se organizam, decidem e buscam superar obstáculos, tendo em vista os conteúdos curriculares, intermediados com as tecnologias e situações da cotidianidade.

Não propomos a apologia das tecnologias, mas a utilização destas como uma das alavancas para refle- xão na sala de aula, como um dos elementos desencadeadores de percepções sobre as complexidades do mundo atual e como mediadoras de processos comunicacionais.

De fato, muito se passa fora da escola e, como conseqüência disso, o professor repetidor, que vê sua missão [apenas] como ensinador do conteúdo disciplinar, tem seus dias contados. Ele será substituído por um vídeo ou por um CDROM, ou por alguma nova peça de tecnologia ainda em desenvolvimento... ele não terá condições de competir com seus "colegas eletrônicos" que desempenham tarefas de repetidores de conhecimento congelado [...] que fala e repete quantas vezes for necessário [...] como o hipertexto, [que] esclarece pontos que não foram bem entendidos, chegando a dialogar com o aprendente. (D’Ambrósio, 2003, p. 60-61)

É lógico que nem todo professor é como o modelo metafórico analisado pelo autor; grande parte dos docentes já se libertou desse papel de ensinador. Hoje, o desafio para a educação vai além do desafio de ensinar com modernas ou tradicionais tecnologias; inclui a realidade que elas comunicam e representam, além da comunicação que propiciam entre pessoas. Com essa concepção, surge para nós o entendimento de que a educação escolarizada é um processo comunicacional democrático, que pressupõe a participação dos sujeitos a partir de seu contexto sociocultural, e transforma-se em um espaço de socialização entre sujeitos e de socialização dos conhecimentos gerados pelos sujeitos; conhecimentos que, quando compartilhados com os outros, exercem seu papel mais amplo: contribuir para que o estudante construa-se e reconstrua-se, abra-se e aproprie-se de seu mundo (Gutiérrez, 2003).

Nesse contexto, o ensino escolarizado não seleciona sujeitos e nem estabelece a priori uma divisão de papéis para professor e aluno, conforme supunha o modelo clássico de comunicação de David Berlo (professor/emissor e aluno/receptor), encaminhando a uma forma linear, unidirecional de ensinar e, conseqüentemente, aprender. Segundo a concepção de edu- 
cação como processo comunicacional, busca-se superar o divórcio entre os pólos emissor/receptor, pois o professor (preparando-se) tem a responsabilidade com a condução e orientação do processo de ensino e com a relação dialógica e plural, que propicia igualdades de oportunidades para os alunos - tradicionalmente entendidos como responsáveis pela recepção da aprendizagem. Assim, distante de práticas unilaterais, a comunicação na escola envolve um agir pedagógico participativo, segundo o qual professores e alunos, estando em movimento, ampliam seus saberes, interações e formas de comunicação com tecnologias propiciadoras de aprendizagens (Porto, 2003).

A escola, segundo esta postura comunicacional, já não é o centro depositário do conhecimento e do saber, mas "o centro de reconhecimento e articulação de múltiplos conhecimentos e informações que circulam, usualmente, para orientar os educandos sobre a forma de como associá-los para seus fins de aprendizado" (Orozco, 2002, p. 68). O professor preserva suas funções, orientando tanto os diversos aprendizados que ocorrem dentro dos sistemas educativos, quanto por aqueles que estão fora e são os meios e tecnologias com os quais os estudantes interagem, assumindo que "a aprendizagem se realiza em múltiplas situações e cenários da vida cotidiana" (idem, ibidem).

Com base nos desafios, caminhos e possibilidades encontrados nas relações dos sujeitos escolares com as tecnologias da informação e comunicação, delineia-se, para nós, a compreensão de uma postura educativa que vai além do uso delas na escola como ferramentas e/ou recursos de um ensino preocupado com a ilustração de proposições, que, freqüentemente, se completa com a tomada da representação pela realidade, subaproveitando a potencialidade reveladora da representação utilizada e distorcendo a realidade que pretende ser focalizada (Porto, 2000). A dimensão dos desdobramentos comunicacionais que as linguagens das tecnologias propiciam é sugestiva de que a relação da escola com os meios precisa superar seu uso como recurso, priorizando as relações vividas/construídas na escola e na sociedade tecnológica, considerando as incertezas e complexidades dos sujeitos e do mundo. Constitui-se ao redor de temas adotados por grupos sociais, observando as condições sociais e os contextos culturais dos sujeitos. Apóia-se em experiências do cotidiano, considerando o que "é visto, ouvido, lido, observado e imaginado" (D’Ambrósio, 2003). Segundo esse entendimento, as escolas promovem situações e vivências, transitando para além dos seus muros, integrando as tecnologias aos conhecimentos de senso comum e aos conhecimentos tradicionais e cientificamente estudados no espaço educativo, despertando, assim, o interesse do aluno para o cotidiano e para o processo de cidadania.

$\mathrm{E}$, se a escola quiser acompanhar a velocidade das transformações que as novas gerações estão vivendo, tem que se voltar para a leitura das linguagens tecnológicas, aproveitando a participação do aprendiz na (re)construção crítica da imagem-mensagem, sem perder de vista o envolvimento emocional proporcionado, a sensibilidade, intuição e desejos dos alunos. Nesse sentido, concordo com Moran (2001, p. 24) quando assegura que a educação escolar pressupõe aprender a "gerenciar tecnologias, tanto da informação quanto da comunicação, e pressupõe [ainda] ajudar a perceber onde está o essencial, estabelecendo processos de comunicação cada vez mais ricos e mais participativos". Ensinar com e através das tecnologias é um binômio imprescindível à educação escolar. Não se trata de apenas incorporar o conhecimento das modernas tecnologias e suas linguagens. É preciso avançar. É preciso ultrapassar as relações com os suportes tecnológicos, possibilitando comunicações entre os sujeitos, e destes com os suportes tradicionalmente aceitos pela escola (livros, periódicos), até os mais atuais e muitas vezes não explorados no âmbito escolar (vídeos, games, televisão, Internet...).

Assim, delineia-se uma postura pedagógica comunicacional de utilização de tecnologias na escola, envolvendo a coordenação de sentidos, combinando comunicações corporais, movimentações, percepções e sensações à leitura e à escrita. Babin e Kouloumdjian (1989) propõem o funcionamento da "escola em estéreo", que significa utilizar duas pis- 
tas, dois tempos no sistema de formação do aluno. Para os autores, as duas pistas significam trabalhar considerando o raciocínio, a cognição, sem deixar de atender aos apelos dos sentidos, das emoções. A afetividade, a imaginação e a análise compreensiva acontecem num entrecruzamento sem sobreposição de uma sobre a outra (Porto, 1998). Os sentidos agem junto às racionalidades como superposição de significantes, combinando e reforçando significados que não mais se assentam em certezas, mas avançam sobre possibilidades, desafios e caminhos em mutação, que superam os estreitos limites da escola racionalista. Nessa outra concepção educativa estão presentes as relações entre o pessoal e o grupal, o sensorial e o racional, o abstrato e o concreto. O conhecimento amplia-se pelas relações que procedem "das diferenciações e pelo alastramento das raízes em busca de novas e mais variadas interfaces" (Santos, 1999, p. 48). Interfaces entre os sujeitos de aprendizagem, e destes com as informações e os conhecimentos presentes tanto nos currículos escolares quanto nas tecnologias e vivências cotidianas.

Apoiando-me nesta concepção paradigmática e com os desafios postos pela prática pedagógica em escolas, busco/trago de dentro deste espaço, ${ }^{1}$ local que entendo ser prioritário para a formação docente em serviço, um pouco da minha experiência com uma pesquisa-ação com alguns meios tecnológicos de comunicação, como forma de interação e produção de saberes entre os sujeitos escolares. Viver e experimentar formação no local de serviço do docente têm me levado a diferentes caminhos dentro da escola básica.

Para tanto, utilizamos a pedagogia da comunicação, área emergente que entende a atividade didática como ato comunicativo e integrador, e vem sendo sis-

${ }^{1}$ A partir deste momento, passo a utilizar dados da pesquisa "Escola pública e pedagogia da comunicação: uma parceria com professores em serviço", realizada com, aproximadamente, 50 professores de $5^{\mathrm{a}}$ à $8^{\mathrm{a}}$ série do ensino fundamental de uma escola pública de Pelotas (RS), com o apoio da FAPERGS e do CNPq, no período de 1997 a 2002. tematizada e utilizada por Gutiérrez e Prado (2000), Penteado (2002) e Porto (2000, 2002, 2003). Procura que os sujeitos escolares convertam-se em consumidores livres, responsáveis e críticos dos meios de comunicação, por meio de diferentes formas de expressão criativa e relação com os temas da cultura estudantil, como forma de aproximação crítica com a realidade social. A incorporação dos meios de comunicação e das linguagens culturais faz com que se desloque a questão da linguagem para além dos códigos escrito e oral que vêm ocupando os professores da escola básica (Penteado, 2002).

\section{Um processo de formação docente com linguagens comunicacionais}

A formação docente, segundo a pedagogia da comunicação, é responsabilidade não só da academia, mas do espaço onde a ação acontece. Uma formação, neste sentido, está aberta a novas experiências, novas maneiras de ser, de se relacionar e de aprender, estimulando capacidades e idéias de cada um; proporcionando vivências que auxiliem professores e alunos a desenvolverem a sensibilidade e a refletirem e perceberem seus saberes (de senso comum) como ponto de partida para entender, processar e transformar a realidade.

Trago não uma pedagogia sobre os meios. Pesquiso e trago uma pedagogia que estabelece comunicação escolar com os conhecimentos, com os sujeitos e seus contextos, considerando os meios de comunicação. Dialoga-se com os meios, em vez de falar deles (Porto, 2000). Assim, em sua complexidade, pode-se dizer que a pedagogia da comunicação é uma abordagem pedagógica processual, que circula entre os sujeitos e os meios tecnológicos a partir de relações entre o senso comum e a ciência, a ação e a reflexão, a razão e a sensibilidade, a objetividade e a subjetividade, o coletivo e o individual, o convencional e o não-convencional.

A metodologia de trabalho adotada para a formação docente compreendeu um conjunto de métodos de comunicação interpessoal e participativos, per- 
mitindo aos professores o entendimento e a compreensão da realidade em suas múltiplas apresentações, e a nós, pesquisadores, a compreensão da realidade escolar e, em especial, dos processos de formação docente em serviço. Foi desenvolvida a partir dos interesses dos sujeitos escolares, da dialogicidade da pesquisadora com os docentes e discentes, destes entre si, e de todo o grupo com algumas tecnologias disponíveis no espaço escolar, o que lhes permitiu maior expressão e diferentes formas de comunicação.

Estabeleci como sistemática prioritária de pesquisa (além do questionário e entrevistas) a realização de encontros (semanais e/ou quinzenais) com os professores do projeto, no próprio local de trabalho, como uma extensão da atividade pedagógica na escola. Todos os encontros foram gravados, com o consentimento delas, embora, a princípio, demonstrassem um pouco de inibição para falar.

No contexto da escola, tive dificuldade em lidar com textos teóricos com que comumente lidamos nos cursos de formação docente. Os professores não demonstravam disponibilidade para realizar leituras (de fundamentação) além daquelas que, em seu ponto de vista, seriam necessárias à profissão: português, matemática etc. A princípio, encaravam a escola como lugar de trabalho, distanciado do processo de sua formação. Tive a preocupação de trazer diferentes linguagens que acentuassem sua participação e não caracterizassem o trabalho como uma aula (ou palestra) dada por um professor universitário. Comecei a criar situações concretas para vivenciar a pedagogia da comunicação.

Então, lancei mão do trabalho com metodologias dialógico-participativas com meios de comunicação, que algumas vezes foram usadas como temas geradores de debates, outras como caminho/recurso para chegar aos objetivos propostos e, ainda, como forma de aproximação e interação entre os sujeitos escolares. Discutimos poesias, crônicas e textos reflexivos sobre a escola, tecnologias, professor e aluno adolescente (sexualidade, drogas). Textos de autores como Rubem Alves (1999), Rodolpho Caniato (1997), Pierre Babin e Marie F. Kouloumdjian (1989) e Paulo Freire e Ira
Shor (1989) foram utilizados para discussão sobre os temas do interesse dos professores. Além desses, selecionei e levei recortes de jornais e de revistas, textos imagéticos (filmes, segmentos de programas televisivos, programas da TV Escola). Ouvimos e conversamos sobre música, houve palestras, oficinas pedagógicas e seminários, vivenciamos dramatizações e psicodramas com histórias e/ou situações socioescolares, vieram professores de outras escolas para apresentar experiências e auxiliar na reflexão sobre os componentes curriculares. Para as oficinas e seminários, procurei trazer convidados que, além de atenderem às solicitações docentes e discentes, trouxessem resultados de pesquisas (para que tivessem contato com o processo, desmistificando-o), que proporcionassem atividades práticas nos diferentes componentes curriculares e que relatassem o uso de experiências (e/ou pesquisas) com tecnologias e temas culturais, conduzindo os docentes à reflexão coletiva. Adotei esta atitude porque acredito que pouco adianta discutir uma metodologia ou assunto " $\mathrm{x}$ " se os professores não tiverem vivenciado experiências nesse sentido. Kramer (1991) e Perrenoud (2000), analisando situação semelhante a estas por nós vivenciadas, sugerem que os mecanismos de formação docente priorizem práticas coerentes com o que se pretende implantar na sala de aula com professores e alunos.

Foram aproveitadas experiências dos docentes adquiridas em contato com as tecnologias da informação e comunicação, com os amigos e com a família. Eles trouxeram para a escola culturas, valores, conhecimentos e atitudes adquiridos nesses contatos. A revitalização e superação dos saberes de senso comum permitiram-lhes uma ligação com os questionamentos de sua época, de seus problemas reais. O contato com o cotidiano desencadeou processos de conscientização e aprendizagem, com a conseqüente aquisição de instrumentos críticos provindos da ciência (Porto, 2000).

Privilegiei o uso de diferentes linguagens para a abordagem do conhecimento e para o estabelecimento de relações entre indivíduos, pois a maioria dos textos pedagógicos abole as emoções, o humor, a iro- 
nia, os sentimentos quando pretendem aproximar-se de uma fala "mais científica", que dificulta a interlocução entre os sujeitos. Para Penteado (2002, p. 23, grifos meus), "cumpre-nos refinar o uso da linguagem oral e escrita com que tradicionalmente trabalhamos [...] e explorar outras linguagens como a pictórica, a musical, a literária, a expressão corporal, a cinematográfica, a televisual". A proposta educativa da autora considera o amplo e diversificado leque de linguagens presentes na sociedade atual, que propicia abordar os objetos de conhecimento, além de possibilitar a comunicação humana e a manifestação de sentimentos, saberes e conhecimentos.

Ainda justificando esses aspectos, encontram-se em Morin (2000) explicações para o uso, pela escola, de diferentes linguagens e expressões comunicacionais, pois incitam à consciência da realidade humana, especialmente nas relações afetivas de pessoa a pessoa. Para o autor, a consciência do caráter complexo da condição humana faz com que o indivíduo seja visto em sua singularidade e subjetividade (buscando compreender suas paixões, amores, ódios, ambições, desejos), e permite sua inserção social e histórica na realidade em que vive. Assim, as diferentes linguagens e expressões comunicacionais possibilitam abordar novas sensibilidades, respeitando as necessidades e os interesses dos sujeitos imersos no mundo tecnológico e audiovisual. Metodologias dialógicoparticipativas com o uso de tecnologias e/ou linguagens imagéticas (fixas e/ou em movimento) servem para os professores refletirem sobre suas individualidades, seus saberes e suas práticas escolares, permitindo-lhes trazer para debate sentimentos, emoções e vivências pessoais (de diferentes períodos de sua vida), assim como terem um outro entendimento e uma outra ação diante de processos e questões do contexto escolar e social. A pesquisa na escola mostrou que, para fundamentar as mudanças pretendidas, os professores necessitavam sentir-se valorizados, exercitar sua capacidade analítica e dialogar sobre vivências pessoais e profissionais, tendo como pano de fundo referenciais teórico-práticos da pesquisadora e deles próprios.
Tal formação vai além de relações lógico-cognitivas proporcionadas pela relação entre sujeitos e textos lineares; vai além do uso das tecnologias como apoio visual, ou seja, mera ilustração do escrito/falado, porque ativam emoções e propiciam associações mobilizadoras de comportamentos e atitudes. De acordo com Ferrés (2000), o espectador vive o que contempla nos meios de comunicação, como expressão simbólica de seus desejos e necessidades, ao mesmo tempo em que vertem sobre ele os desejos, conferindo-lhe sentido. As imagens e os sons presentes nas tecnologias, em especial nos meios de comunicação e informação, privilegiam a comunicação afetiva, permitindo ao expectador um "mergulho" nas sensações proporcionadas no contato com elas. No entender de Babin (1993, p. 24), a emoção propiciada pela imagem "liga-se diretamente à excitação sensorial [...] situa-se entre o psíquico e o físico, e comporta uma forte tonalidade afetiva [...] a emoção modifica o corpo todo".

É interessante observar que os conhecimentos expressos pelos professores, relacionados com suas práticas, estudos e leituras (de formação inicial e continuada), trazem para discussão na escola aspectos de sua identidade, carreira, processos de formação e saberes que dizem respeito ao exercício da profissão, à subjetividade e aos relacionamentos vividos/construídos ao longo da vida.

Em minha pesquisa-ação, o uso de dialogicidade, de diferentes ferramentas tecnológicas e metodologias comunicacionais que trabalham com o corpo e com as emoções/sensações dos docentes, serviram para resgatar imagens de sua infância/adolescência, contribuindo para que eles refletissem sobre si mesmos (comunicação intrapessoal) e percebessem sentidos e significados (vividos, planejados, superados, imaginados, vencidos, não alcançados...), racionalizando sobre seu potencial de sujeito adulto professor. Esses momentos foram importantes, pois lhes permitiram refletir sobre sua identidade, sua essência, expressando-se de forma natural e espontânea.

Discutimos as coisas, compartilhamos, nós somos subsidiadas com materiais, combinamos e os alunos gostam

Revista Brasileira de Educação $\quad$ v. $11 \quad$ n. 31 jan./abr. 2006 
mais... isso acrescenta um pouco o sentimento de que não estamos sozinhas... amplia nossas relações e aprendemos com os outros [...] é o único momento que compartilhamos, mesmo não entrando em consenso, na diversidade a gente aprende mais com os outros. (Professora de história, grifos meus)

Momentos em que os professores puderam expressar seus sentimentos e percepções, permitindolhes ultrapassar as racionalidades, os compromissos e responsabilidades de ser professor, trabalhando sua auto-estima.

Através de linguagens comunicacionais, eles trouxeram recordações de tempos e espaços de serem criança, jovem, pai, mãe, cidadão da vida de relações. $\mathrm{O}$ conhecimento e a recuperação desses tempos e espaços contribuem para que os professores relembrem, falem e reflitam sobre os papéis vividos, recuperando os processos que os levaram a constituir-se professor (comunicação intrapessoal) e a refletir e buscar melhores relações na escola (comunicação interpessoal), auxiliando na compreensão dos limites, medos, prazeres, desejos e inseguranças de seus alunos (Porto, 2003).

Observei, ainda, que os professores sentiram-se à vontade para expressar, com linguagens corporais e pictóricas, aspectos do cotidiano vivido e discutido, principalmente em relação à profissão. É válido observar algumas falas de docentes de $5^{\mathrm{a}}$ e $8^{\mathrm{a}}$ série, respectivamente, oriundas de diálogos em situações dramatizadas e/ou em construção de painéis imagéticos:

[...] então, depois da aula o professor sai assim (imagem de um homem com cabelos em pé) e chega em casa todo despencado. Chega em casa, tem outros problemas.

Aqui eu coloquei também o grupo. O grupo com idéias e discussão. Aqui idéias luminosas, e aqui o aluno feliz! Nosso objetivo (imagem de professores e alunos trabalhando integrados). Esta forma de trabalho faz aflorar percepções e situações de ser aluno.

O trabalho com imagem possibilita a participação ativa do espectador, que a trata como "parceiro ativo, emocional e cognitivamente" (Aumont, 1993, p. 81), porque ele reconhece nela alguma coisa que vê ou pode ser visto no real. A imagem convoca o indivíduo a completar seu entorno. Funciona como uma dobradiça, articulando "o interior do sujeito, seus desejos, suas idéias, motivações e conhecimentos, com os elementos do mundo real. Os indivíduos buscam informações que lhes sejam úteis [...] utilizam-se das representações pessoais e sociais para criar e/ou recriar valores e conceitos, tornando-se operadores de mensagens" (Porto, 2003, p. 97).

As concepções que remetem à compreensão dos desejos docentes retratam reflexões e significados atribuídos aos seus saberes. Nesse sentido, as imagens internalizadas na trajetória pessoal e profissional dos docentes, obtidas através de jogos dramáticos e/ou de segmentos de programas televisivos, servem como intermediação entre os professores e suas emoções/ ações vividas na escola e na realidade mais ampla.

A utilização de linguagens imagéticas em atividades de formação docente em serviço (segundo Burgos, 1998; Porto, 2002) baseia-se no reconhecimento de que este processo/instrumento de trabalho:

- não substitui a palavra, ocupa outro lugar na construção de sentidos;

- evidencia discursos ou construções discursivas que representam configurações espaçotemporais de sentido;

- permite desvendar, com mais força que a palavra, representações conscientes e inconscientes sobre problemáticas educativas;

- tem mais força de expressão para detonar e identificar conflitos e estereótipos subjacentes às práticas, trabalhando com eles;

- contribui para que os professores tenham elementos para "rupturar" e decidir em momentos aparentemente complexos e fechados.

\section{Um processo de formação docente com temas do cotidiano discente}

Tradicionalmente, as escolas têm se preocupado com os conteúdos curriculares a serem vencidos. Esta 
prática desagrada muitos professores e estudantes que entendem que o currículo deve conter temas relevantes e atraentes às experiências discentes, conectandoos com a vida e a realidade social em que vivem. No entender desses professores, é importante que sejam valorizados os saberes e experiências dos alunos; muitos deles, porém, admitem ter dificuldade para lidar com essas situações devido a falhas observadas em seu processo de formação e/ou de trabalho.

Esta necessidade é enfatizada também por Gutiérrez e Prado (2000), Morin (2000) e D’Ambrósio (2003), para quem a educação institucionalizada, ainda que tenha como meta o domínio da cultura, tem que abordar o cotidiano ou será inevitavelmente neutralizada por ele. Não sugiro o abandono da função cultural clássica da escola, substituindo os conteúdos do currículo, mas entendo que a escola, junto com a responsabilidade de transmitir e produzir conhecimentos, precisa abrir-se às novas formas culturais, aos problemas próximos de seus sujeitos, às diferentes (e, para alguns, novas) formas de comunicação.

Para Morin (2000), o professor tem o dever de educar-se sobre o mundo e sobre a cultura dos estudantes para que possa responder às questões e curiosidades deles, preenchendo lacunas entre o mundo do professor (adulto), o mundo do aluno (criança e jovem) - na maioria das vezes em contato com as tecnologias - e o dos conhecimentos escolares. Os conteúdos presentes nas tecnologias da comunicação, em especial na televisiva, fornecem elementos para expressão e compreensão de processos sociais, pois trazem para a cena conflitos, estereótipos, situações e contextos a serem debatidos/refletidos pelos sujeitos escolares (também espectadores), muitas vezes com dificuldades para, sem orientação, lerem imagens e perceberem conexões montadas pelos meios para "vender" seus produtos, idéias e serviços.

Mas como levar esses temas para o dia-a-dia da sala de aula?

Trazendo para debate situações e temas da realidade discente, comparando-as com o tratamento dado pelos meios de comunicação às questões polêmicas, pude auxiliar os professores a prepararem-se para ori- entar os alunos a estabelecerem relações entre o seu cotidiano, o do meio e o da sociedade, percebendo significados e criações para esses temas.

A reflexão no coletivo de professores sobre temas do interesse discente e a leitura crítica das mensagens/imagens contidas nos meios de comunicação permitem-lhes sentirem-se mais seguros e preparados para tratar destes temas em sala de aula. Muitas vezes, a maior dificuldade em lidar com alguns assuntos (tais como sexualidade e violência, entre outros) origina-se de "pré-conceitos" dos docentes e da não-presença deles nos livros didáticos, ferramenta prioritária usada com alunos em sala de aula por professores do ensino fundamental (Porto, 2002). As discussões com os pares sobre as informações observadas nos programas televisivos auxiliam na assunção de atitudes e comportamentos e na reflexão (docente) sobre preconceitos e estereótipos que povoam o senso comum da maioria dos sujeitos, determinando e estabelecendo papéis a serem incorporados por todos. Assim, o adulto, antes de tratar o tema com seus alunos, precisa ser ouvido e ouvir-se, conhecer o conteúdo e conhecer-se, sentindo-se capaz de (re)conhecer seus preconceitos, tabus e, principalmente, seus limites para conduzir assuntos polêmicos (Porto, 2003). Nesse sentido, os professores, refletindo sobre as informações presentes nos meios de comunicação, observam que a realidade neles retratada é uma construção social, e a orientação docente pode auxiliar os alunos a uma leitura crítica e, conseqüentemente, a uma intervenção na realidade.

\section{Algumas conclusões}

Os meios de comunicação resultam e compõemse de idéias, projetos, interesses, utopias e estratégias que afetam de diferentes formas os indivíduos e as instituições. Mas, embora eles sejam portadores de mensagens, a mensagem educativa maior está no seu efeito sobre o aluno, e é esta mensagem que a escola precisa recuperar para, a partir dela, realizar, completar e ampliar a aprendizagem (Kenski, 2003). Eles veiculam informações a serem trabalhadas segundo a 
concepção de quem as vê ou usa - neste caso, os sujeitos escolares. Não há um sentido único nessa relação; assim, contribuem para a emersão de mediações, significados e saberes que propiciam movimentos na escola, dependendo, essencialmente, dos contextos, pessoas, tempos e relações que com eles são mantidas.

Professores e alunos, imersos nas culturas dos meios de comunicação, trazem para a escola temas aí presentes, com pontos de identificação com seus cotidianos culturais. A convivência com os jovens estudantes e os trabalhos realizados com os docentes e tecnologias/meios de comunicação evidenciaram a importância educativa de um recurso que a escola tem deixado de utilizar: a própria vida.

Os meios destacam e privilegiam a apreensão de aspectos do cotidiano, trabalhando com propriedade diferentes linguagens e conexões visuais, auditivas e narrativas, para chegar, por meio da fantasia, da imaginação e da sensibilidade, ao receptor. Eles não entram "pela via da razão em nosso interior, mas, atropelando as emoções e percepções, entram pela janela, sem que tenhamos sentido o menor barulho" (Merlo, 2003 , p. 175). Ao contrário do que acontece com os textos escolares, os meios de comunicação (em especial televisão, rádio e cinema) lidam com nexos entre pessoas, palavras, imagens e sons que são compreendidos e desfrutados pelos sujeitos pelas vias da sensibilidade antes de chegar ao intelecto. Por exemplo, os ouvintes e telespectadores de programas de televisão e rádio reagem física e psicologicamente ao visto/ouvido antes de apreender o significado do texto. Há, primeiramente, um impacto emocional provocado pela sucessão de estímulos. Completando esses dados, trazemos o pensamento de Ferrés (2000), para o qual a imagem é a representação concreta da experiência, enquanto a linguagem verbal é uma abstração da experiência.

Assim, por ser dinâmico e multissensorial o universo dos jovens, o trabalho com imagens dos meios tecnológicos de informação e comunicação possibilita-lhes a gratificação sensorial, visual e auditiva, permitindo-lhes que estabeleçam associações entre fatos e vivências. Ainda de acordo com o autor, como o império da imagem restitui à cultura o sentido do imediato, ele é potencializado tanto pelo ritmo trepidante do discurso das tecnologias de comunicação quanto pelo caráter concreto de seus significantes, potencializando o dinamismo e imediatismo dentro do qual o jovem vive em seu cotidiano.

Os estudantes relacionam-se com os meios tecnológicos e de comunicação, apreendendo as mensagens/imagens que lhes sejam úteis e que mais se adaptem ao seu modo de ver. Nesse sentido, alguns autores (Porto, 2000; Ferrés, 2000; Barreto, 2002) mostram que a ficção e o entretenimento presentes nesses meios têm grande influência sobre os comportamentos e atitudes sociais dos estudantes, que introjetam modelos mais significativos segundo sua percepção. O uso que podem fazer das mensagens/informações presentes nos meios é um material muito rico; indica não só elementos de diversão e aprendizagem dos jovens, mas também manifestação de sua interioridade; ou seja, é uma forma de conhecermos melhor nossos alunos, de sabermos que têm visão seletiva, utilizam-se de representações para compor sua leitura, criar ou recriar conhecimentos/caminhos, adquirindo, com um trabalho pedagógico comunicacional, autonomia conceitual e emocional.

O trabalho escolar com as tecnologias de comunicação e informação supõe mudar a ordem do processo educativo, no qual, tradicionalmente, o professor decide arbitrariamente o que ensinar. Segundo essa postura, a decisão não é só sua; depende de articulações entre professor e alunos, e destes com as tecnologias, através das "múltiplas situações e cenários da vida cotidiana [...] fazendo com que a aprendizagem seja resultante de um processo significativo e relevante para o sujeito" (Orozco, 2002, p. 68).

Numa pedagogia da comunicação, a reflexão sobre temas do cotidiano discente e a construção de elementos expressivos de sua cultura - produzida com e através dos meios de comunicação - desenvolvem no sujeito uma compreensão mais elaborada e conscientizada sobre a realidade. Essa pedagogia permite partir da cultura básica do aluno, de sentido comum, adquirida em contato com o cotidiano e as tecnologias, 
em direção a uma cultura mais elaborada, capaz de conscientizar os alunos de sua realidade.

Assim, a escola, ao utilizar temas do cotidiano discente e linguagens tecnológicas e comunicacionais em processos de formação docente:

- trabalha com um material que faz parte do diaa-dia dos sujeitos escolares e é agradável a eles;

- introduz a vida na escola, chegando por meio de textos imagéticos às inquietudes, interesses e dúvidas de professores e alunos sobre temas vitais;

- envolve os docentes em experimentações pedagógicas com novas linguagens;

- faz aflorar percepções e situações vividas no dia-a-dia, que interferem em sua prática profissional;

- propicia aprendizagens para além das racionalidades, envolvendo sensibilidade, intuição, emoção e desejo;

- possibilita interação entre os professores, destes com os estudantes, e de ambos com os conhecimentos escolares e as tecnologias;

- aumenta o poder de decisão e de criação dos sujeitos;

- colabora não só com a formação do sujeito crítico, mas conduz à formação do cidadão crítico.

\section{Referências bibliográficas}

ALVES, Rubem. Entre a ciência e a sapiência; o dilema da educação. São Paulo: Loyola, 1999.

AUMONT, Jacques. A imagem. Campinas: Papirus, 1993.

BABIN, Pierre. El linguaje de la nueva cultura. Madrid: Paulinas, 1993.

BABIN, Pierre; KOULOUMDJIAN, Marie F. Os novos modos de compreender : a geração do audiovisual e do computador. São Paulo: Paulinas, 1989.

BARRETO, Raquel G. Formação de professores; tecnologias e linguagens. São Paulo: Loyola, 2002.
BURGOS, Alícia Villagra de. El uso de la imagen en los programas de formación del profesorado de los nuevos medios. In: GUTIÉRREZ MARTÍN, Alfonso (Coord.). Formación del profesorado em la sociedad de la información. Segovia, Espanha: Escuela Universitaria de Magistério, 1998. p.159-183.

CANIATO, Rodolpho. Consciência na educação. Campinas: Papirus, 1997.

D’AMBRÓSIO, Ubiratan. Novos paradigmas de atuação e formação de docente. In: PORTO, Tania M. E. (Org.). Redes em construção: meios de comunicação e práticas educativas. Araraquara: JM Editora, 2003. p. 55-77.

FERRÉS, Joan. Televisión, emoción y educación. In: VALDERRAMA, H. C. E. (Ed.). Comunicación-educación. Bogotá: Siglo del Hombre, 2000. p. 131-154.

FREIRE, Paulo; SHOR, Ira. Medo e ousadia: o cotidiano do professor. São Paulo: Paz e Terra, 1989.

GUTIÉRREZ MARTÍN, Alfonso. El discurso tecnológico de los nuevos medios: implicaciones educativas. Comunicar, Huelva/ES, n. 18, p. 90-95, mar./jul. 2002.

. El profesor ante las nuevas tecnologías multimedia.

In :__ Formación del profesorado em la sociedad de la información. Segovia, Espanha: Escuela Universitaria de Magisterio, 1998. p. 13-29.

GUTIÉRREZ, Francisco. Dimensão pedagógica das novas tecnologias da comunicação e informação. In: PORTO, Tania M. E. (Org.). Redes em construção: meios de comunicação e práticas educativas. Araraquara: JM Editora, 2003. p. 33-40.

GUTIÉRREZ, Francisco; PRADO, Cruz. Ecopedagogia e cidadania planetária. 2. ed. São Paulo: Cortez, 2000.

KENSKI, Vani Moreira. Tecnologias e ensino presencial e a distância. Campinas: Papirus, 2003.

KRAMER, Sônia. Dando vez ao mestre (entrevista). Presença Pedagógica, Belo Horizonte, n. 4, p. 5-21, 1991.

LÉVY, Pierre. Cibercultura. São Paulo: Editora 34, 2000.

MARCOLLA, Valdinei. A inserção das tecnologias de informação e comunicação no espaço de formação docente na UFPEL. Pelotas: UFPEL/Faculdade de Educação, 2004.

MERLO, Tatiana. A imagem como símbolo cultural. In: PORTO, Tania M. E. (Org.). Redes em construção: meios de comuni- 
cação e práticas educativas. Araraquara: JM Editora, 2003. p. 145-179.

MORAN, José M. Novos desafios na educação - a Internet na educação presencial e virtual. In: PORTO, Tania M. E. (Org.). Saberes e linguagens de educação e comunicação. Pelotas: Editora e Gráfica da Universidade Federal de Pelotas, 2001. p.19-44.

MORIN, Edgar. Os setes saberes necessários à educação do futuro. 2. ed. São Paulo: Cortez / UNESCO, 2000.

OROZCO, Guilhermo G.. Comunicação, educação e novas tecnologias: tríade do século XXI. Comunicação e Educação, São Paulo, n. 23, p. 57-70, jan./abr. 2002.

PENTEADO, Heloisa D. Comunicação escolar: uma metodologia de ensino. São Paulo: Salesiana, 2002.

PERRENOUD, Philippe. Novas competências para ensinar. Porto Alegre: Artmed, 2000.

PORTO, Tania M. E. A comunicação na escola e a formação do professor em ação. In: (Org.). Redes em construção: meios de comunicação e práticas educativas. Araraquara: JM Editora, 2003. p. 79-110. Educação para a mídia/pedagogia da comunicação.

In: PENTEADO, Heloisa D. (Org.). Pedagogia da comunicação: teorias e práticas. São Paulo: Cortez, 1998. p. 23-49.

As mídias e os processos comunicacionais na formação docente na escola. In: REUNIÃO ANUAL DA ANPEd, 25. Caxambu: CD-ROM, 2002.
A televisão na escola... afinal que pedagogia é esta? Araraquara: JM Editora, 2000.

QUIROZ, Maria Tereza; TEALDO, A. R. Videojuegos o los compañeros virtuales. Lima, Peru: Universidad de Lima, 1996.

SANTOS, Boaventura de Sousa. Um discurso sobre as ciências. Porto, Portugal: Afrontamento, 1999.

SARLO, Beatriz. Escenas de la vida posmoderna. Buenos Aires: Ariel, 1998.

TANIA MARIA ESPERON PORTO, doutora em educação pela Universidade de São Paulo (USP), é professora do Programa de Pós-Graduação em Educação da Faculdade de Educação da Universidade Federal de Pelotas (UFPel). Foi coordenadora do GT 16 - Educação e Comunicação da ANPEd, no período de 2002 a 2004. Principais publicações: A televisão na escola... afinal que pedagogia é esta? (Araraquara, SP: JM Editora, 2000); Medios de comunicación y formación en servicio de los docentes (Comunicar, Huelva/Espanha, n. 18, p. 53-59, 2002); A comunicação na escola e a formação do professor em ação (In: PORTO, T. M. E. (Org.). Redes em construção: meios de comunicação e práticas educativas. Araraquara: JM Editora, 2003).E-mail: taniaporto@terra.com.br

Recebido em julho de 2004 Aprovado em setembro de 2005 
rando a necessidade de se repensar o sistema educacional, principalmente no que diz respeito às questões curriculares. Destaca a importância do movimento do software livre, enquanto portador de filosofia centrada na cooperação e no trabalho coletivo, ressaltando a importância desse movimento para a educação.

Palavras-chave: tecnologia educacional; educação e comunicação; informática educativa; Internet; tecnologias da informação e comunicação (TIC); software livre.

Technologies and new educations This article analyses contemporary society considering the transformations that have taken place in the realms of science, culture and education. It is considered important to bring culture and education back together and incorporate information and communication technologies (ICT) into them. We examine the progress of ICT as well as the movement towards the monopolisation of the mass media and present work being carried out in the Faculty of Education at UFBA in training teachers. We consider it necessary to rethink the educational system, curricular issues in particular. We highlight the importance of the open source movement as promoting a philosophy based on co-operation and collective work and therefore of great importance to education.

Key-words: teaching technology; education and communication; computer education; Internet; information and communication technology (ICT); open source software

\section{Tecnologías y nuevas educaciones}

El artículo analiza la sociedad contemporánea, a partir de las transformaciones del mundo científico, tecnológico, cultural, social y educativo, con el objetivo de hacer una crítica a este. Considera importante la reaproximación entre la cultura y la educación, entendidas en el plural, y de éstas con las tecnologías de la información y comunicación (TIC). Aborda los progresos de las TICs y los movimientos de concentración en la propiedad de los medios de comunicación de masa, hace su crítica, y presenta las propuestas en estudio en la Facultad de Educación de UFBA, para la formación de profesores, considerando la necesidad de repensar en el sistema educacional, principalmente lo referente a las cuestiones curriculares. Destaca la importancia del movimiento del sofware libre, en cuanto portador de filosofía, centrada en la cooperación y en el trabajo colectivo, mostrando lo importante que es este movimiento para la educación.

Palabras claves: tecnología educacional; educación y comunicación; informática educativa; Internet; tecnologías de la información y comunicación (TIC); sofware libre

Raquel Goulart Barreto, Glaucia Campos Guimarães, Ligia Karam Corrêa de Magalhães e Elizabeth Menezes Teixeira Leher

As tecnologias da informação e da comunicação na formação de professores

$\mathrm{O}$ artigo discute os modos de objetivação das tecnologias da informação e comunicação (TIC) na formação de professores. Com base em teses e dissertações defendidas entre $1996 \mathrm{e}$ 2002, analisa elementos e relações visando ao mapeamento de três tendências de incorporação educacional das TIC: como estratégia para o desenvolvimento de diversas propostas de ensino a distância; como possibilidade de aperfeiçoamento do ensino presencial; e como elemento-chave para a constituição de um ensino virtual.

Palavras-chave: tecnologias; formação de professores; modalidades de ensino
The technologies of information and communication in the training of teachers

This text aims to discuss how technologies of information and communication (ICT) are used in the teachers' education. Based on theses and dissertations, defended between 1996 and 2002, it analyses discrete elements and relations with the aim of mapping three trends in the incorporation of ITC: (1) as a strategy to develop diverse distance learning programmes; (2) as a possibility for improving teaching-learning processes; and (3) as the key to e-learning. Key-words: technologies; teachers' education; teaching modes

Las tecnologías de la información y de la comunicación, en la formación de profesores

El artículo discute los modos de objetividad de las tecnologías de la información y comunicación (TIC) en la formación de profesores. Con base en tesis y disertaciones defendidas entre 1996 y 2002, analiza elementos y relaciones, direccionado a la descripción de tres tendencias de incorporación educativa de las TICs: como estrategia para el desenvolvimiento de diversas propuestas de enseñanza a distancia; como posibilidad de perfeccionamiento de la enseñanza presencial; y como elemento clave para la constitución de una enseñanza virtual

Palabras claves: tecnologías; formación de profesores; modalidades de la enseñanza

Tania Porto

As tecnologias de comunicação e informação na escola; relações possíveis... relações construídas Estamos diante de novas maneiras de compreender, de perceber, de sentir e de aprender, nas quais a afetividade, a imaginação e os valores não podem deixar de ser considerados. Apesar de a es- 
cola ainda privilegiar a "cognição", os jovens estudantes não se interessam tanto pelos conteúdos e temas de estudos como pelas relações que se estabelecem (ou podem ser estabelecidas) no ambiente escolar, mediadas por tecnologias da comunicação. Neste artigo, pretendo, inicialmente, refletir sobre as relações entre a ação educativa escolar e as tecnologias, para, num segundo momento, mostrar como chegar a um processo de formação docente na escola, com o uso dos meios de comunicação. Referimo-me a um conjunto de procedimentos e meios tecnológicos que põem em discussão questões individuais, referentes aos interesses e subjetividades dos sujeitos, e questões sociais, referentes aos ambientes socioculturais dos quais os indivíduos participam. A escola e os meios tecnológicos de comunicação assemelham-se porque tratam da realidade e ambos são local de aquisição de saberes; assim, educar com os meios e educar para os meios é imprescindível à educação escolar por possibilitar um ambiente favorável à cotidianidade.

Palavras-chave: tecnologias; meios de comunicação; linguagens na escola

Technologies of communication and information in schools: possible relation... constructed relations We are facing new ways of understanding, perceiving, feeling and learning within which affection, imagination and values cannot be left aside. Although school still highlights "cognition", the young students are not so much interested in the contents and themes of their studies, as much as they are interested in the relationships that are (or can be) established in the school environment, mediated by technologies of communication. In this paper, initially, I intend to reflect upon the relations between school educational action and technology, to show, later on, how I have devised a process of teacher training in schools with the help of the media. I am referring to a set of procedures and technological means which put in discussion individual questions, related to the interests and the subjectivity of individuals, and to social questions, related to the socio-cultural environments in which individuals participate. The school and the technological means of communication are similar inasmuch as they both deal with reality and are place for acquiring knowledge; thus, to educate with the media and for the media is indispensable for school education because it allows the creation of an favourable environment to daily life.

Key-words: technology; communication media; languages in school

Las tecnologías de comunicación e información en la escuela; relaciones posibles... relaciones construídas

Estamos delante de nuevas maneras de comprender, de percibir, de sentir y de aprender, en las cuales, la afectividad, la imaginación y los valores no pueden dejar de ser considerados. A pesar de la escuela todavía privilegiar la “cognición”, los jóvenes estudiantes no se interesan tanto por los contenidos y temas de estudios como por las relaciones que se establecen (o pueden ser establecidas) en el ambiente escolar, mediadas por las tecnologías de la comunicación. En este artículo, pretendo, inicialmente, reflexionar sobre las relaciones entre la acción educativa escolar y las tecnologías, para, en un segundo momento, mostrar como llegar a un proceso de formación docente en la escuela, con el uso de los medios de comunicación. Me refiro a un conjunto de procedimientos y medios tecnológicos que ponen en discusión cuestiones individuales, alusivos a los intereses y subjetividades de los sujetos y cuestiones sociales, referentes a los ambientes socioculturales de los cuales los individuos participan. La escuela y

los medios tecnológicos de

comunicación se asemejan, porque

tratan de la realidad y ambos son

locales de adquisición de saberes; así, educar con los medios y educar para

los medios es imprescindible a la

educación escolar, por posibilitar un

ambiente favorable a la cotidianidad.

Palabras claves: tecnologías; medios de comunicación; lenguajes en la escuela

Laura Macrina Gómez Espinoza

El desplazamiento de prácticas impresas y la apropiación de prácticas digitales. Un estudio con alumnos del bachillerato tecnológico aprendiendo a usar la computadora en la escuela

Se presenta una investigación cualitativa con perspectiva sociocultural sobre las prácticas lectoescritoras de ocho díadas de estudiantes de bachillerato tecnológico, al realizar tareas escolares utilizando la computadora. Se analizan datos recopilados mediante observación participante utilizando grabaciones en audio y video, lo que lleva a reconocer distintas prácticas de lectoescritura a partir del tipo de producción y conocimiento de los programas computacionales que se requieren para su realización. Los hallazgos revelan que tales prácticas se van transfigurando de lo impreso hacia lo digital conforme las producciones se tornan más complejas, y se ponen en práctica conocimientos y acciones más sofisticadas. Se concluye que las tecnologías de información y comunicación están propiciando el acceso a mundos con múltiples formas de leer y escribir, apuntado hacia una relación de complementariedad con el mundo impreso; esto lleva a reconsiderar el papel de la educación en la formación de lectores/escritores críticos, versátiles, creativos y competentes. 